\title{
STRATEGIC SCM THROUGH INFORMATION TECHNOLOGY TO \\ ENCOUNTER RECESSION-AN EMPIRICAL STUDY BASED ON SELECTED FIRMS IN BANGALORE CITY
}

\author{
* Dr. Cynthia Menezes Prabhu
}

\begin{abstract}
In these current trying times of the global meltdown, Companies need to strategise more than ever for maintaining competitiveness in their respective industry. One of the strategies that companies utilise for cost effectiveness is the use of Supply Chain Management (SCM). SCM helps the Company to maintain an agile profile in the industry by providing real time information and thereby creating strategic business and trading partners. SCM mandatorily requires the use of information technology to be effectively implemented. The theme of this paper is how companies make use of information technology to implement SCM techniques in their business. An empirical study was conducted among fifteen selected firms based in Bangalore city and answers elicited by means of a questionnaire. The paper has been divided into parts such as an introduction, usefulness of SCM in times of recession, information technology as a means for effective implementation of SCM, profile of respondents, the analysis of the questionnaire, due findings and the concluding remarks.
\end{abstract}

Key words: Supply Chain Management (SCM), Information Technology (IT)

\subsection{Introduction:}

Recession requires the industry to be cost effective and agile in terms of procuring, manufacturing and out bound logistics. Being cost effective means being able to manufacture at the lowest possible cost of production and thereby offer competitive rates for any products or services produced by the Company. Only in such circumsatnces can the firm be competitive in all phases in its respective industry. as compared to the other firms in the same industrial environment. Being competitive means being able to survive and being successful in times of recession.

\subsection{Usefulness of SCM in times of recession:}

Supply chain management is an enabler for firms to improve their overall competencies. Firms can focus on their core competencies and network with the best possible service providers they require, who can contribute to making the value chain more efficient. Inhouse maintainance of all facilities is not necessary because effective and timely outsourcing can be done of any services, thereby enabling the firm to have least amount of resources on hand and save up on unnecessary costs. Specialisation of core competencies is also possible by effective networking for outsourcing of services through SCM.

Canara Bank School of Management Studies, Bangalore University, Bangalore

menezescynthia@gmail.com / c_menezes@ rediffmail.com

Cell: 9902554503,9845914196 


\subsection{Information technology as a means for effective implementation of SCM:}

Information technology is a time saving and effective means for channel partners to trade goods, share information, and integrate their processes. Inter organizational dynamics can be reshaped, and more efficient channels can be utilised making the entire process of inbound logistics, manufacturing and outbound logistics more effective. Integration of data can be done electronically and the automation of business practices can make processes more cost effective. Better sales are possible through proactive measures thereby better satisfying consumer needs. Paper based transactions and communications are a siower process. Real time information is a critical competitive resource that creates inherent core competencies for the firm in the industry. Information Technology infrastructure capabilities enable competitive positioning of business initiatives like cycle time reduction and implementing redesigned cross-functional processes. Real time information is a critical success factor in times of recession and further enables the reduction of inventory and human resource requirement to a competitive level. Real time information is a major requirement for strategic planning. The importance of real time information in the supply chain also stems from the fact that market forces can demand changes within suppliers, logistics providers, locations. customers and any of the business trading partners in the supply chain networks. Information technology makes it possible to give real time information so that the firm can stay agile within its industry.

\subsection{Profile of respondents:}

On a judgemental basis, fifteen firms were selected for the said survey and the results are given herein.

TABLE ONE

\begin{tabular}{|c|c|c|c|c|}
\hline $\begin{array}{c}\text { SI. } \\
\text { No. }\end{array}$ & $\begin{array}{c}\text { o. of Employees in } \\
\text { the Plant }\end{array}$ & $\begin{array}{c}\text { No. of Years of } \\
\text { Operation of the } \\
\text { Plant }\end{array}$ & $\begin{array}{c}\text { No. of Years of } \\
\text { Operation of the } \\
\text { Plant }\end{array}$ & Industry \\
\hline 1 & $500-1000$ & $<5$ & MANUFACTURING \& DISTRIBUTION & PHARMA \\
\hline 2 & 250 & $<5$ & MANUFACTURING & CHEMICALS \\
\hline 3 & $500-1000$ & $<5$ & MANUFACTURING \& DISTRIBUTION & SOLAR SOLUTIONS \\
\hline 4 & $200-500$ & $<5$ & MANUFACTURING \& DISTRIBUTION & GRANITE \\
\hline 5 & $<1000$ & $5-10$ & MANUFACTURING \& DISTRIBUTION & FOOD PROCESSING \\
\hline 6 & $>1000$ & $5-10$ & MANUFACTURING \& DISTRIBUTION & PHARMA \\
\hline 7 & $>1000$ & $10-20$ & MANUFACTURING \& DISTRIBUTION & ENGINEERING \\
\hline 8 & $200-500$ & $10-20$ & MANUFACTURING & ENGINEERING \\
\hline 9 & $500-1000$ & $10-20$ & MANUFACTURING \& DISTRIBUTION & ENGINEERING \\
\hline 10 & $>5000$ & $10-20$ & MANUFACTURING \& DISTRIBUTION & AUTOMOBILE \\
\hline 11 & $>1000$ & $10-20$ & MANUFACTURING & CEMENT \\
\hline 12 & $>1000$ & $10-20$ & MANUFACTURING \& DISTRIBUTION & STEEL \\
\hline 13 & $>2000$ & $>20$ & MANUFACTURING \& DISTRIBUTION & PHARMA \\
\hline 14 & $>5000$ & $>20$ & MANUFACTURING & AUTOMOBILES \\
\hline 15 & $>5000$ & $>20$ & MANUFACTURING \& DISTRIBUTION & AUTOMOBILE \\
\hline
\end{tabular}

Source: Primary data 
Three of the above respondent companies are from the Pharma, engineering and automobile sectors, one each from the steel, granite, food processing, chemicals, solar solutions and cement sectors. An attempt has been made to mobilise responses from as many sectors as possible given the paucity of time. Since a fairly good distribution over various sectors has been done, it is assumed that the answers elicited represent those from a varied segment of industry.

\section{5: Analysis and findings:}

1.5.1 Information technology as an instrument to encounter recession: All the companies surveyed agreed that the use of information technology helps them to have cost effective strategies apart from having good relationships with their trading partners. This aids them to battle the ongoing recession, with varied degrees of success by using real time information

1.5.2 IT Tools/solutions used in Companies: Companies use different IT tools or solutions based on their individual firm requirement. IT tools may be of different applications from various companies' perspective. The following table shows the different tools used by companies.

TABLE TWO

\begin{tabular}{|c|c|c|}
\hline FIRMS & RESPONSES & RANK \\
\hline ERP & 8 & TWO \\
\hline Bar coding and Scanning & 2 & FIVE \\
\hline Web based EDI & 2 & FIVE \\
\hline Extranet & 4 & FOUR \\
\hline Internet & 15 & ONE \\
\hline Intranet & 5 & THREE \\
\hline
\end{tabular}

Source: Primary data

The most popular tools used by firms is the internet since all the firms surveyed used the internet. ERP tools are used by eight firms and are therefore ranked second. Five firms use intranet and four use extranet. Bar coding and scanning as well as web based EDI is used by only two firms each and therefore get ranked five in terms of usage as an IT tool for SCM.

1.5.3 Intra Firm Information System Used: This part deals with the usage of intra firm information system used within the organization. Communication plays a vital role in passing the important information and the intra firm information system is useful for the same. These systems also play a role in maintaining and managing communications within individual departments in the company. The following table gives the details. 
TABLE THREE

\begin{tabular}{|l|c|l|}
\hline \multicolumn{1}{|c|}{ FIRMS } & NUMBER OF RESPONDENTS & RANK \\
\hline Inventory management system & 9 & FOUR \\
\hline Distribution planning system & 11 & TWO \\
\hline MRP & 9 & FOUR \\
\hline ERP & 7 & FIVE \\
\hline Intranet & 12 & ONE \\
\hline Transportation management system & 10 & THREE \\
\hline Warehouse management system & 7 & FIVE \\
\hline
\end{tabular}

Source: Primary data

Intranet is the most popular intra firm information system, being used by twelve firms and therefore gets ranked one. Distribution planning system is used by eleven companies and gets ranked two, followed by transportation management system which is used by ten firms and gets rank three. Inventory management system and MRP are ranked four since they are used by nine firms, ERP and warehouse management systems are used by seven firms each and are therefore ranked five in order of usage.

1.5.4 IT connectivity between various trading partners: This section deals with the IT connectivity established between various trading partners of a company. IT connectivity helps different partners for better communication and co-ordination. IT connectivity may be between Head office and branch offices, may be between head office and factory or distributors or any trading partners. IT connectivity helps the company in many ways and increases the level of transparency in doing business.

TABLE FOUR

\begin{tabular}{|l|c|l|}
\hline \multicolumn{1}{|c|}{ FIRMS } & NUMBER OF RESPONDENTS & RANK \\
\hline Head Office and Trading partner & 9 & THREE \\
\hline Head Office and distributor & 8 & FOUR \\
\hline Head Office and factory & 13 & TWO \\
\hline Head Office and Branch Office & 14 & ONE \\
\hline
\end{tabular}

Source: Primary data

Out of the respondents, 9 use IT connectivity between Head office and Trading partners, 8 use IT connectivity between Head office and distributor, 13 use IT connectivity between Head Office and factory and 14 use IT connectivity between Head office and branch Office. It connectivity seems to be the most important between the head office and its branches as most firms use it, followed by communication between the head office and factory. Intra organisational communication has been given more importance than communication with external trading partners. 
1.5.5 Networking Used in Companies: This part deals with the type of networking used in the companies. There may be different kinds of networking used in the company, but only a particular type of network suits the work culture of that company. Below is the table of responses.

TABLE FIVE

\begin{tabular}{|l|c|c|}
\hline \multicolumn{1}{|c|}{ FIRMS } & NUMBER OF RESPONDENTS & PERCENTAGE \\
\hline Value Added Network & 5 & 33.33 \\
\hline Private Area Network & 2 & 13.33 \\
\hline WAN & 4 & 26.66 \\
\hline LAN & 4 & 26.66 \\
\hline
\end{tabular}

Source: Primary data

Most of the firms surveyed use Value Added Networks (VANs) for networking purposes as five firms among the respondents have used VANs for this purpose. WANs and LANs also seem to be popular as is evident from the table because four firms use these services for networking. Private Area Networks are least used by firms for networking since only two of the respondent companies use this service.

\subsubsection{Strategic Advantages of implementing IT solutions in Organizations:}

TABLE SIX

\begin{tabular}{|l|c|l|}
\hline \multicolumn{1}{|c|}{ FIRMS } & NUMBER OF RESPONDENTS & RANK \\
\hline Better Collaboration & 10 & FIVE \\
\hline Improved Communication & 12 & TWO \\
\hline Greater Flexibility & 9 & SIX \\
\hline Increased efficiency & 13 & ONE \\
\hline Reduced cycle time & 13 & ONE \\
\hline Lower operating costs & 11 & THREE \\
\hline Increased revenue & 12 & TWO \\
\hline Higher profit margin & 10 & FOUR \\
\hline
\end{tabular}

Source: Primary data 
The respondent firms have opined that the most benefits acquired from having information technology enabled SCM is increased efficiency and reduced cycle time. Increased revenue and improved communications are the next best achievements of IT enabled SCM. Lower operating costs, followed by higher profit margins and then by greater flexibility in operations are the other benefits derived through IT enabled SCM by the surveyed firms.

\subsection{Concluding remarks:}

Increased efficiency, reduced cycle time, improved communications, lower operating costs and greater flexibility are competitive strategies that keep a firm agile in its industry environment. The surveyed firms were of the opinion that being competitive is the best way to battle the times of recession. Survival and success in terms of enhanced revenue as well as higher profit margins are also achieved through IT enabled SCM, as is evident from the study.

\section{REFERRED READINGS FROM :}

1. Drew, S. \& Coulson. Thomas, C., (1997) "Transformation through team work" The path I to the new organization, Team performance Management.

2. Bearnon, B.M (1998), "Supply Chain design \& analysis: Models \& Methods," International Journal of Production Economics.

3. Cooper, M.C., Lambert, D.M., \& Pagh, J. (1997) Supply Chain Management: More Than a New Name for Logistics. The International Journal of Logistics Management.

4. AKP C Swain, Research Methodology, Kalyani Publications, $2^{\text {na }}$ revised edition.

5. S Chopra, Supply Chain Management, Prentice - Hall of India, 2003.

With grateful thanks to Chethan C.V. for aiding in the collection of data. 